LAW AND THE SOCIAL WORKER 
Related titles from Macmillan

Zofia T. Butrym: THE NATURE OF SOCIAL WORK

Olive M. Stone: FAMILY LAW 


\title{
LAW AND THE
}
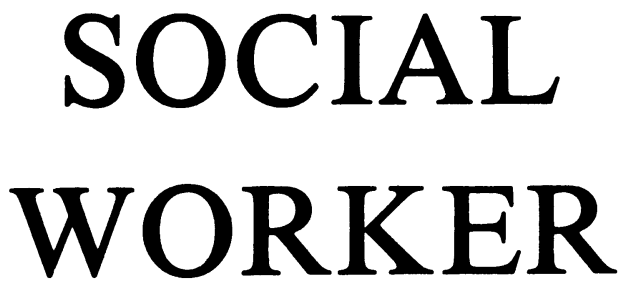

\author{
B. L. Raisbeck T.D., LL.B., A.C.I.S.
}

Lecturer in Law at the

University of Manchester

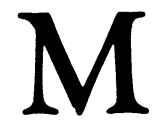


(c) B. L. Raisbeck 1977

Softcover reprint of the hardcover 1st edition 1977 978-0-333-19110-1

All rights reserved. No part of this publication

may be reproduced or transmitted, in any form

or by any means, without permission.

First published 1977 by

THE MACMILLAN PRESS LTD

London and Basingstoke

Associated companies in New York Dublin

Melbourne Johannesburg and Madras

ISBN 978-0-333-19111-8 ISBN 978-1-349-86155-2 (eBook)

DOI 10.1007/978-1-349-86155-2

This book is sold subject to the standard conditions of the Net Book Agreement.

The paperback edition of this book is sold subject to the condition that it shall not, by way of trade or otherwise, be lent, re-sold, hired out, or otherwise circulated without the publisher's prior consent in any form of binding or cover other than that in which it is published and without a similar condition including this condition being imposed on the subsequent purchaser. 


\section{Contents}

Preface

1 The Legal System

Introduction

Rules of Law

Jurisdiction

Costs and Legal Aid

2 The Social Worker and the Court 14

Introduction $\quad 14$

Evidence in Criminal Proceedings 15

Evidence in Civil Proceedings 19

Silence as Evidence $\quad 21$

Procedure in the Courtroom 22

Reports for the Courts $\quad 27$

Conclusion 31

3 Powers, Duties and Responsibilities 34

Introduction $\quad 34$

General Legal Powers $\quad 35$

Confidentiality $\quad 39$

Vicarious Liability $\quad 43$

Conclusion $\quad 44$

4 Juveniles: Prevention and Voluntary Action 45 
Introduction $\quad 45$

Preventive Action $\quad 45$

Voluntary Care $\quad 47$

Supervision $\quad 53$

5 Juveniles: Compulsory Treatment 64

Introduction $\quad 64$

Assumption of Parental Rights 65

Care Proceedings $\quad 71$

Place of Safety Orders $\quad 83$

Place of Safety Warrant $\quad 86$

Criminal Proceedings $\quad 88$

Conclusion $\quad 91$

6 Adoption 93

Introduction $\quad 93$

Capacity 93

Placing for Adoption $\quad 95$

$\begin{array}{ll}\text { Actual Custody } & 97\end{array}$

Supervision and Inspection $\quad 98$

$\begin{array}{lr}\text { Consents } & 100\end{array}$

Freeing Child for Adoption 101

Dispensing with Consent 102

Consent of Spouse 107

Consent of Other Natural Parent 107

The Guardian Ad Litem 108

The Hearing $\quad 112$

7 Mental Health 114

Introduction $\quad 114$

Mental Disorder $\quad 114$

Compulsory Admission to Hospital 116

Discharge from Hospital 121

Mental Health Review Tribunal 123

$\begin{array}{ll}\text { Guardianship } & 127\end{array}$

The Criminal Courts 128

The Powers and Duties of the Social Worker 131

8 Marriage Breakdown 134

$\begin{array}{ll}\text { Introduction } & 134\end{array}$ 
The Magistrates' Court 134

The Divorce Court $\quad 140$

Involvement of the Social Worker 144

$\begin{array}{ll}\text { Conclusion } & 148\end{array}$

$\begin{array}{lr}\text { Further Reading } & 149\end{array}$

$\begin{array}{ll}\text { Index } & 151\end{array}$ 


\section{Preface}

Having lectured for some years on the legal aspects of social work on such courses as the M.A. in Social Administration, the Diploma in Social Work and various regional and in-service training courses for social workers I have become increasingly aware of the need for an introductory book in this area. In response to the demand from past and present students I embarked on the task of writing such a book as a basic introduction in, I hope, a readable style.

Limitation on space and the need to suit the pocket of the student and unqualified social worker decreed that despite genericism in social work there had to be selectivity in the book. The accent, therefore, is on 'professional law' as described by the Central Council for the Education and Training of Social Workers - that is, the legal framework within which social workers function and the basic legal rules which govern their activities as such. Scant attention is paid to advisory law as I consider there is some danger in attempting to advance beyond the frontiers of professional law in a basic training course, and in that area even a little legal learning can be more dangerous than useful. Nevertheless, because of the increasing direct involvement of social workers in matrimonial disputes where the welfare of children is in issue I have inserted a short chapter on marriage breakdown.

A major distraction to social workers attempting to gain some legal knowledge by studying legal textbooks is the abundance of footnotes citing authorities for statements made by the author. I have therefore accepted the challenge of writing a book which does not attempt to be 
a legal book and which does not contain footnotes, albeit cross-references in the text are unavoidable. The book does not aspire to be a vade-mecum for all social workers confronted with a legal problem, but rather a work to be read before embarking on legal study in depth.

I make no apology for the attention paid to evidence and court procedure; I believe that a basic knowledge of the rules governing admissibility of material in court and of the procedure in the inferior courts is essential to every social worker even though his involvement in such proceedings may be indirect. Although he may never appear as a party or as a witness he should nevertheless be aware of the rules governing the activities of his colleagues and of other social workers fulfilling a role different to his own.

Some questions are raised and left unanswered; in some areas discussion in greater depth will be required; but provided the basic problems are mentioned and occasionally the reader's appetite is whetted then I think a primary objective has been realised.

I hope that this short book will be helpful to trainees and other social workers as well as being worth reading for magistrates, their clerks and all those who have interest or involvement in this area of activity. Its conception was the result of feedback from social workers on initial training courses and in practice; its gestation and birth were greatly assisted by the patience and tolerance of its publishers. For any genetic and perinatal defects I accept full responsibility. 